GABRIEL BOROWSKI

https://orcid.org/0000-0002-2565-4815

Uniwersytet Jagielloński

gabriel.borowski@uj.edu.pl

\title{
AŻ DRESZCZ BIERZE: O PRZEKŁADZIE POLSKIEGO ŚWIADECTWA HOLOKAUSTU NA BRAZYLIJSKĄ PORTUGALSZCZYZNĘ 1
}

\begin{abstract}
It Gives You Shivers: Translating Polish Holocaust Testimony into Brazilian Portuguese

In this article, I try to lay out clearly and discuss selected issues encountered during the translation (with Eda Nagayama) of Bogdan Bartinkowski's collection of stories Dzieciństwo w pasiakach (1969) into Brazilian Portuguese. My text combines a scholarly dimension with one of self-commentary in order to offer some general reflection on the subject of the ethics of translating testimony. It consists of three parts. In the first, I provide a concise overview of the state of research on the connections between translation and studies on cultural memory. Next, I present a series of observations relating to the emotional dimension of the process of translating Holocaust testimonies. In the final section, I compare solutions adopted in translations of Bartnikowski's memoir into German, English, Italian, Spanish, French, Russian, and Portuguese. In the conclusions, I try to define the memory-(re)productive role of translation: reproductive, in that the translation of testimony demands a respect for the truth of the signs present in the original and their rendering in the target culture; and productive (creative) inasmuch as it demands of the author of the translation a series of procedures with the aim of inscribing a universal theme within the specific field of cultural memory.
\end{abstract}

1 Niniejszy tekst powstał dzięki wsparciu programu SPECTRESS (Social Performance, Cultural Trauma and the Reestablishing of Solid Sovereignties), w ramach którego w sierpniu i wrześniu 2017 roku przebywałem na Uniwersytecie w São Paulo. 
Keywords: translation, cultural memory, Holocaust testimony, Holocaust literature, Brazil, Bogdan Bartnikowski

Słowa kluczowe: przekład, pamięć kulturowa, świadectwa Holokaustu, literatura Holokaustu, Brazylia, Bogdan Bartnikowski

W powieści z 1976 roku zatytułowanej Chłopcy z Brazylii, stanowiącej podstawę nominowanej do Oscara ekranizacji z 1978 roku z Gregorym Peckiem i Laurence'em Olivierem w rolach głównych, Ira Levin - autor między innymi bestsellerowego Dziecka Rosemary - snuje wizję, w której ukrywający się po wojnie w Ameryce Południowej Josef Mengele dąży do sklonowania Adolfa Hitlera w celu przywrócenia III Rzeszy (Levin 1992). W wydanej osiem lat później w książce Roberto Drummonda Hitler manda lembranças (Drummond 1984) jeden z głównych bohaterów, były więzień obozów w Auschwitz i Buchenwaldzie, ściga „Anioła Śmierci” po ulicach brazylijskiego miasta Belo Horizonte. Obydwie fikcje, z pozoru absurdalne, nabierają innego, złowieszczego wydźwięku, jeśli weźmie się pod uwagę ustalony dopiero w 1985 roku fakt, że Mengele rzeczywiście po wojnie ukrywał się w Brazylii, gdzie w 1979 roku utonął w miejscowości Bertioga w stanie São Paulo.

Ponad dwadzieścia lat później, pod koniec stycznia 2008 roku, brazylijska szkoła samby Unidos do Viradouro otrzymuje sądowy nakaz rozbiórki nawiązującego do Holokaustu pojazdu w kształcie stosu wychudzonych ciał, który w lutym tego samego roku miał zostać zaprezentowany jako część programu zatytułowanego „É de arrepiar!” (Aż dreszcz bierze!; Viradouro $2008)^{2}$ podczas znanego na całym świecie pochodu karnawałowego w Rio de Janeiro. Reżyser pokazu w geście protestu włącza do korowodu nowy pojazd, na którym umieszcza nieruchome, zakneblowane postaci w białych strojach z olbrzymim transparentem: „não se constrói futuro enterrando a história" (przyszłości nie buduje się, grzebiąc historię), co wzbudziło ostrą polemikę ${ }^{3}$.

${ }^{2}$ W pokazie nawiązywano również m.in. do karaluchów, pająków i węży, skazańców na krzesłach elektrycznych i na gilotynach, czarownic palonych na stosach oraz postaci z filmów Egzorcysta, Laleczka Chucky, Edward Nożycoręki i Obcy (https://www.youtube.com/ watch? $\mathrm{v}=$ MvMeY1LI8w).

${ }^{3} \mathrm{~W}$ dyskusjach wokół wydarzenia zestawiano m.in. ostrą reakcję środowisk żydowskich w Brazylii na platformę Unidos do Viradouro z ogólnym brakiem znaczącego oporu wobec 
Powyższe przykłady odsyłają do szeregu napięć istotnych z punktu widzenia reprezentacji pamięci o Szoa w kulturze brazylijskiej. Największy kraj Ameryki Południowej jest miejscem rzeczywistej (w przypadku Mengelego) i fikcyjnej (w powieściach Levina i Drummonda) kontynuacji traumy Holokaustu, a jednocześnie, jak pokazuje przykład Viradouro, jego problematycznej karnawalizacji. Jak zauważył Márcio Seligmann-Silva (2007), Szoa stanowi w literaturze brazylijskiej temat „skrajnie marginalny”, co może dziwić, zważywszy że dla wielu żydowskich uchodźców Brazylia stanowiła „bezpieczny brzeg” (DiAntonio 1991). Sam termin „Holokaust” pojawia się ostatnio w brazylijskim dyskursie publicznym w odmiennych kontekstach, między innymi w tytule bestsellerowego reportażu Holocausto brasileiro Danieli Arbex (2013) poświęconego zakładowi dla psychicznie chorych w miejscowości Barbacena w stanie Minas Gerais, gdzie do końca lat 70. XX wieku z powodu nieludzkich warunków życia zmarło co najmniej 60 tysięcy osób.

Ta specyfika dyskursu o Szoa w Brazylii okazała się istotna, gdy w 2017 roku na zamówienie Wydawnictwa Państwowego Muzeum Auschwitz-Birkenau przygotowywałem wraz z pisarką i badaczką Edą Nagayamą tłumaczenie na brazylijską odmianę języka portugalskiego wspomnień byłego więźnia obozu w Oświęcimiu, Bogdana Bartnikowskiego (ur. 1932 r.), opublikowanych oryginalnie w 1969 roku pod tytułem Dzieciństwo w pasiakach (Bartnikowski 2016a) i dostępnych już wówczas w języku niemieckim, angielskim, włoskim, hiszpańskim i francuskim, a wkrótce także rosyjskim. Praca nad przekładem wymagała udzielenia odpowiedzi na wiele pytań związanych z tym, co redaktorzy tomu Translating Holocaust Lives (Boase-Beier et al. 2017) wskazują jako potencjalny konflikt pomiędzy obszarami zainteresowania Holocaust Studies i translatologii, wynikający ze zderzenia moralnego imperatywu możliwie wiernego oddania tekstu źródłowego z koniecznością dostosowania tłumaczenia do potrzeb obcojęzycznego odbiorcy.

W niniejszym artykule dążę do uporządkowania i omówienia wybranych problemów translatorskich, łącząc wymiar badawczy z elementami autokomentarza, aby podjąć ogólną refleksję na temat etyki przekładu świadectwa. Szkic składa się z trzech części. W pierwszej proponuję zwięzły przegląd aktualnego stanu badań nad związkami przekładoznawstwa i studiów nad

przedstawień brazylijskiego niewolnictwa w ramach wcześniejszych pochodów karnawałowych, jak również na ogólną nieprzystawalność ahistorycznej wizji świata w czasie karnawału z żydowskim imperatywem zachowania przeszłości poprzez pamięć (Bines 2011). 
pamięcią kulturową. Następnie przedstawiam szereg uwag dotyczących emocjonalnego wymiaru samego procesu tłumaczenia świadectwa Holokaustu. W ostatniej sekcji zestawiam z sobą rozwiązania przyjęte $\mathrm{w}$ przekładach wspomnień Bartnikowskiego na język niemiecki, angielski, włoski, hiszpański, francuski, rosyjski i portugalski (Bartnikowski 2018b) ${ }^{4}$.

\section{Przekład i pamięć}

\section{Jak zauważa Wulf Kansteiner,}

Pamięć o Holokauście stanowiła jedno z pierwszych pełnoprawnych zbiorowych wspomnień o charakterze transnarodowym, przemierzających półkulę północną pod postacią atrakcyjnych przykładów symbiozy obrazu i tekstu (imagext) i jednoczących odbiorców z różnych krajów w postrzeganiu podobnych wydarzeń medialnych (2017: 305).

Zdaniem badacza analiza wspomnień ofiar Holokaustu od zawsze kształtowała pojęciową infrastrukturę studiów nad pamięcią, w szczególności w odniesieniu do koncepcji pamięci transnarodowej. Proces ten dokonuje się w dużej mierze poprzez przekład umożliwiający powstanie wielojęzycznej wspólnoty odbiorców. Zaskakująca okazuje się tym samym stosunkowo słaba i rozproszona obecność dyskursu naukowego poświęconego związkom badań nad pamięcią i badań nad przekładem (Kershaw 2018), szczególnie jeśli zauważymy za Tomaszem Bilczewskim (2013: 41), że co najmniej dwa dynamicznie rozwijające nurty w ramach przekładoznawstwa - feministyczny i postkolonialny - czerpały obficie z odniesień do zjawisk o charakterze traumatycznym.

Rozważając tę kwestię od strony Memory Studies, można zauważyć, że wyzwanie przekraczania granic pomiędzy dyscyplinami postulowane w ramach badań pamięciologicznych to często sprawa problematyczna. Jak twierdzi Kornelia Kończal, „wbrew popularności głoszonego życzeniowo i normatywnie hasła «interdyscyplinarność», badania nad pamięcią charakteryzują się wciąż podziałami” (2014: 9). Do podobnych spostrzeżeń

${ }^{4}$ Dziękuję Wydawnictwu Państwowego Muzeum Auschwitz-Birkenau za udostępnienie przekładów na pozostałe języki: niemiecki (Bartnikowski 2016b), angielski (Bartnikowski 2016c), włoski (Bartnikowski 2016d), hiszpański (Bartnikowski 2016e), francuski (Bartnikowski 2016f) i rosyjski (Bartnikowski 2018a). Ze względu na moją ograniczoną znajomość języka rosyjskiego przykłady z tego tłumaczenia pojawiać się będą znacznie rzadziej. 
dochodzą Magdalena Saryusz-Wolska i Robert Traba, redaktorzy leksykonu Modi memorandi, którzy zaznaczają, że choć liczni polscy badacze podkreślają interdyscyplinarny charakter swoich projektów, ,jeśli (...) przyjrzeć się spisom treści i programom wystąpień, łatwo dostrzec, że owa «interdyscyplinarność» była raczej słowem wytrychem niż poważnie rozumianym wyzwaniem badawczym" (Saryusz-Wolska, Traba 2014: 14). Już parę lat wcześniej Saryusz-Wolska stwierdziła zresztą:

Badania nad pamięcią mają więc obecnie charakter wielodyscyplinarny, ale tylko w niewielu przypadkach są rzeczywiście inter- lub transdyscyplinarne. Wzajemne słuchanie się i zapoznawanie $\mathrm{z}$ dorobkiem badaczy preferujących odmienne podejścia stanowi natomiast dobry, a zarazem niezbędny początek, by w przyszłości przekraczać granice poszczególnych dziedzin. Rozwój tej tendencji może być jednak dwojaki. Albo w toku coraz liczniejszych spotkań osób zajmujących się tą problematyką wykształci się pewna wspólnota dyskursu, pozwalająca na realne interdyscyplinarne porozumienie, albo też będziemy musieli pogodzić się z istniejącymi różnicami, pozwalając sobie na komunikację, która chwilami będzie powierzchowna i niedokładna (2010: 80).

O braku realnej „wspólnoty dyskursu” pomiędzy badaniami nad pamięcią i badaniami nad przekładem świadczyć może zresztą sama struktura leksykonu Modi memorandi, który „dopełnia trwającą od schyłku lat 80 . XX w. międzynarodową debatę na temat badań pamięci, systematyzując i podsumowując stan teoretycznej refleksji” (Saryusz-Wolska, Traba 2014: 13), ma charakter pierwszego „kompleksowego opracowania, które oferowałoby przegląd całej problematyki i umożliwiało porównanie różnych stanowisk” (14) i proponuje wybór pojęć według kryterium „możliwości zastosowania ich w badaniach i interpretacjach zjawisk mieszczących się w ramach kultury pamięci” (24). Próżno szukać w spisie treści (czy chociażby w indeksie) tej encyklopedii hasła ,przekład”, mimo że kwestia problematycznego wyboru wariantów tłumaczeniowych w przypadku haseł obcojęzycznych zostaje wyraźnie podkreślona we wstępie (24). Podobną lukę dostrzec można w innych tomach pamięciologicznych wydanych w Polsce w ostatnich latach: Pamięć jako kategoria rzeczywistości kulturowej (Adamowski, Wójcicka 2012) - choć tutaj na uwagę zasługuje obecność sekcji poświęconej „pamięci językowej” - oraz Kultura jako pamięć. Posttradycyjne znaczenie przeszłości (Hałas 2012), Pamięć i afekty (Budrewicz, Sendyka, Nycz 2014) i Historie afektywne i polityki pamięci (Wichrowska et al. 2015). 
Spore postępy czyni pod tym względem przekładoznawstwo po tak zwanym zwrocie kulturowym, w ramach którego ,z poziomu filologicznego uwaga przeniesiona zostaje na poziom polityki i etyki" (Heydel 2009: 23). O stopniowej konsolidacji zagadnienia świadczą w szczególności opracowania monograficzne i wydawnictwa zbiorowe. Wymienić tu można między innymi numer specjalny czasopisma „Translation and Literature” pod redakcją Petera Daviesa (2014), poświęcony przekładowi świadectw Holokaustu, oraz niewielką, bo składającą się z zaledwie czterech artykułów, sekcję „Memory and Translation” w kanadyjskim czasopiśmie ,TranscUlturAl” (Malena 2016). Szczególnie znaczące są książki: Memoria, lingua, traduzione pod redakcją Mirelli Agorni (2014), Translating the Poetry of the Holocaust. Translation, Style and the Reader autorstwa Jean Boase-Beier (2015), Translating Holocaust Literature pod redakcją Petera Arndsa (2015), Mapping Memory in Translation Siobhan Brownlie (2016), Translating Holocaust Lives pod redakcją Boase-Beier, Daviesa, Andrei Hammel i Marion Winters (2017), oraz Daviesa Witness between Languages. The Translation of Holocaust Testimonies in Context (2018). Istotnym krokiem na tej ścieżce powinien być zapowiadany tom Handbook of Translation and Memory, który w 2020 roku ma ukazać się nakładem wydawnictwa Routledge (Spiessens 2018).

Za sprawą tych i innych publikacji dostrzec można zalążki radykalnej reorientacji paradygmatu charakteryzującej się zmianą w sposobie postrzegania relacji między obydwiema dyscyplinami. Redaktorzy tomu Translating Holocaust Lives stwierdzają, że „,coraz trudniej jest pominąć zagadnienie przekładu w badaniach nad świadectwami Holokaustu, choć pełen wkład tłumaczy i dziedziny przekładoznawstwa w powstanie i przekaz wiedzy o Holokauście wciąż jeszcze nie został dostatecznie zauważony" (Boase-Beier et al. 2017). Davies przestrzega przed ograniczeniem roli przekładoznawstwa do krytyki negatywnej:

Obydwa obszary badań zdają się zderzać i przeczyć sobie nawzajem w takim stopniu, że jeśli zagadnienie przekładu pojawia się w badaniach na świadectwami Holokaustu, to wyłącznie w kontekście skandali albo jako bezproduktywne, obronne skargi dotyczące „zdrady” cennego oryginału (2018: 1).

Sam Davies zdecydowanie podkreśla doniosłą rolę przekładu w studiach nad Zagładą jako zjawiskiem wielojęzycznym i wielokulturowym. Stwierdza wręcz, że „bez przekładu nie byłoby Holokaustu” (Davies 2018: 3), ponieważ tłumaczenie wpisane jest w strukturę samego pojęcia, wyrosłego na gruncie badań naukowych, praktyk upamiętniania i dyskursu politycznego. 
Przyznaje, że zrezygnował z pierwotnego pomysłu na tytuł swojej książki - „Translating the Holocaust” - ponieważ zakładałoby to, że pojęcie Holokaustu istnieje przed przekładem $i$ wymaga jedynie transferu $z$ jednego języka do drugiego, podczas gdy jego zdaniem ,powstaje [ono] poprzez przekład i przekład jest w nie wpisany od samego początku” oraz „zależy od przekładu i nie mogłoby bez niego istnieć” (Davies 2018: 5-6).

Jak podkreślają między innymi Angela Kershaw (2018) i Anneleen Spiessens (2018), dla wypracowania owocnej poznawczo optyki w obydwu dyscyplinach istotne są w szczególności analizy przekładu rozumianego dosłownie - „przekładu właściwego” (Jakobson 2009; por. Dizdar 2009) a nie tylko metaforycznie, jako reguły międzypokoleniowej transmisji lub sposobu ujmowania doświadczenia Zagłady w ramy językowe. Tego rodzaju analizie poświęcona jest dalsza część tego artykułu.

\section{Tłumacz jako świadek}

Niniejszy szkic poświęcony jest tekstowi nienależącemu do „kanonicznych” świadectw Holokaustu, które jako przedmioty dobrze znane i mające istotny wpływ na wyobrażenia o Zagładzie w świecie anglojęzycznym zdominowały badania nad związkami przekładu i Zagłady (Boase-Beier et al. 2017). Dzieciństwo w pasiakach to stosunkowo niewielki, liczący około 200 stron zbiór opowiadań przedstawiających losy dzieci w obozie koncentracyjnym, oparty na doświadczeniach autora, który w sierpniu 1944 roku został osadzony wraz z matką w KL Auschwitz-Birkenau. Tom ukazał się po raz pierwszy w 1969 roku nakładem wydawnictwa Nasza Księgarnia i był przez nie parokrotnie wznawiany $(1972,1977,1989)$, a od 2007 roku figuruje w ofercie Wydawnictwa Państwowego Muzeum Auschwitz-Birkenau. Nakładem wydawnictwa PMAB ukazały się przekłady zbioru na języki: niemiecki (Eine Kindheit hinterm Stacheldraht, przeł. Werner Hölscher-Valtchuk, 2008), angielski (Childhood behind Barbed Wire, przeł. Tomasz Pobóg-Malinowski, 2009), włoski (Infanzia dietro il filo spinato, przeł. Anna Lia Guglielmi Miszerak, 2010), hiszpański (Infancia en traje de rayas, przeł. Fernando Bravo García, 2010) oraz francuski (Une enfance en pyjama rayé, przeł. Alexandre Dayet, 2016). W 2016 roku zamówiono kolejne dwa przekłady: na rosyjski (Dietstwo w połosatych robach, przeł. Nadieżda Iwaniec) oraz na portugalski (a konkretnie - na portugalszczyznę brazylijską), który został powierzony mnie. Do współpracy zaprosiłem Edę Nagayamę - pisarkę, 
autorkę miedzy innymi zbiorów opowiadań Palavracidade (2013) i Traço comum (2013) oraz nowel Desgarrados (2015) i Yaser (2018), związaną z Wydziałem Filozofii, Literatury i Nauk Humanistycznych Uniwersytetu w São Paulo. Projekt obejmował pracę nad tłumaczeniem, które miało stanowić wynik negocjacji znaczeń między oryginałem powstałym w języku polskim, nieznanym mojej współtłumaczce, a tekstem docelowym, mającym wpisać się w brazylijską rzeczywistość językowo-kulturową.

Na szczególną uwagę w kontekście badań nad przekładem świadectw Zagłady zasługuje specyfika samego procesu tłumaczenia ujmowanego pod kątem emocjonalnej odpowiedzi tłumacza na tekst nasycony opisami przemocy wobec dzieci i dorosłych, głodu, tortur i cierpienia. Opisy te budzą głęboką reakcję twórcy tekstu docelowego, czyli ,autora konkretnych słów, które wychodzą z ust świadka" (Heydel 2018: 270). Wszak, jak podkreśla Magda Heydel, ,z jednej strony tłumacz ma (...) nad świadkiem władzę, ponieważ kształtuje jego wypowiedź, z drugiej natomiast świadectwo zyskuje władzę nad tłumaczem, zmusza do wzięcia udziału w wydarzeniach, przyjęcia pozycji uczestnika" (Heydel 2018: 271). Jak zauważa natomiast Séverine Hubscher-Davidson w monografii Translation and Emotion. A Psychological Perspective (2017), chociaż większość praktyków i badaczy przekładu jest zgodna co do tego, że afektywne zaangażowanie empatycznego tłumacza - a w szczególności tłumacza literatury - stanowi przeważnie warunek osiągnięcia satysfakcjonującej jakości tekstu przekładu, bardzo niewiele uwagi poświęcono do tej pory zarówno percepcji, jak i reekspresji emocji w procesie thumaczenia.

Praca nad Dzieciństwem w pasiakach potwierdziła spostrzeżenia Hubscher-Davidson dotyczące emocjonalnego wymiaru pracy nad przekładem. Utwór ukazuje głównie cierpienie dzieci, często odbierane jako synekdocha bezbronności więźniów w ogóle, co sprzyja międzykulturowej identyfikacji (por. Anderson 2007) i może wywoływać silną reakcję afektywną. Świadczą o tym komentarze „,nieprofesjonalnych” czytelników oryginału, którzy zestawiają niewielką objętość zbioru z intensywnością doświadczenia lektury. Jedna z czytelniczek stwierdza na portalu Lubimy Czytać: „Pomyślałam... Ledwie ponad sto stron... Spróbuję... Mimo niewielkiej ich ilości czułam, jakby było ich minimum 500"5. Inna wyznaje:

5 http://lubimyczytac.pl/ksiazka/68333/dziecinstwo-w-pasiakach/opinia/2677556\# opinia2677556 (dostęp: 21.11.2018). 
Dzieciństwo w pasiakach to bardzo trudna lektura. Pomimo że czytam dużo i mogę spędzić z książką parę godzin, nie odkładając jej, w tym wypadku było inaczej. To jedna z najcieńszych książek, jakie przeczytałam w życiu, i jedna z tych, którą czytałam najdłużej. Trawiłam po kilka opowiadań i nawet nie codziennie ${ }^{6}$.

Przekład tej niewielkiej pozycji okazał się przedsięwzięciem silnie obciążającym psychicznie, co uniemożliwiało pracę w przewidywanym pierwotnie tempie i ukończenie zlecenia w zaplanowanym terminie dwóch miesięcy. Retrospektywnie można uznać, że błędem strategicznym było niemalże całkowite $^{7}$ i często wielogodzinne skupienie na tłumaczeniu zamiast regularnej i krótszej pracy oraz oddania się różnorodnym działaniom zapewniającym psychiczną równowagę, co Hubscher-Davidson nazywa ,przestrzenią emocjonalną” konieczną do „przetrawienia wykonanej pracy” i do autorefleksji. Nasze doświadczenia okazały się zbliżone do omawianej przez badaczkę sytuacji Jeanne Holierhoek i Janneke van der Meulen, tłumaczek powieści Les Bienveillantes Jonathana Littella z 2006 roku na język niderlandzki. Podobnie jak w ich przypadku, praca w tandemie, stwarzająca możliwość wymiany doświadczeń i rozmowy nad emocjonalnymi reperkusjami procesu tłumaczenia, okazała się czynnikiem przynoszącym ulgę. Wiązało się to z drugą istotną okolicznością, to jest refleksją metajęzykową. Regularna dyskusja nad systemowymi różnicami między językami, odmiennością realiów historycznych, społecznych i kulturowych, nad problematycznymi rozwiązaniami przekładowymi i poszukiwaniami właściwego głosu dla zmieniających się narratorów i fokalizatorów stwarzały możliwość zmiany perspektywy i wyjścia niejako poza tekst, co pozwalało na lepszą kontrolę jego formy ${ }^{8}$.

${ }^{6}$ http://lubimyczytac.pl/ksiazka/68333/dziecinstwo-w-pasiakach/opinia/44975517 \#opinia44975517 (dostęp: 21.11.2018). Przywołać można dodatkowo fragmenty parudziesięciu innych opinii z portalu: „w książce prawie na każdej stronie można przeczytać słowa, które zapadają w pamięć”; ,książka wstrząsa, bo mowa w niej o doświadczeniach na ludziach i o bestialstwie”; ,przez cały czas czytania książki tak bardzo pragnęłam jej końca”; „,nie jest to pierwsza książka o tematyce obozowej, którą czytałam. (...) Ale jeszcze żadna, naprawdę żadna książka nie doprowadziła mnie do łez tak jak ta...”,; ,wstrząsająca lektura”; ,w krótkiej, prostej formie zawiera ogromną dawkę emocji”; ,jedna z najtrudniejszych książek w moim życiu. Nie chcę już do niej wracać, bo jej czytanie za bardzo boli”; ,jeśli ktoś się zapyta, jaka jest najdrastyczniejsza książka jaką czytałam, bez namysłu wskażę Dzieciństwo w pasiakach" (http://lubimyczytac.pl/ksiazka/68333/dziecinstwo-w-pasiakach, dostęp: 21.11.2018).

7 Przekład powstał w większości podczas mojego pobytu w São Paulo w ramach stypendium SPECTRESS, co sprzyjało koncentracji na samym tłumaczeniu.

${ }^{8}$ Zjawiska te zbliżone są do m.in. do doświadczeń Désirée Schyns, tłumaczki wspomnień Sarah Kofman Rue Ordener, rue Labat (1994) na język niderlandzki, stanowiących 
Proces dystansowania się wobec tekstu oryginalnego przez refleksję o charakterze formalnym skłaniać może do podjęcia dyskusji nad etycznym aspektem pracy tłumacza świadectwa. Możliwość - a wręcz konieczność przynajmniej częściowego odcięcia się od wstrząsającej nieraz treści utworu pozostaje poniekąd w opozycji do imperatywu otwarcia się na świadectwo pierwotne, uważnego wysłuchania go i wiernej transmisji. Problem ten wiąże się ściśle z domniemaną potrzebą dążenia przez tłumacza świadectwa do efektu przezroczystości (Heydel 2018), jako że jego istnienie jako pośrednika pomiędzy autentycznym doświadczeniem świadka a jego odbiorcą w innym języku jest zdaniem Daviesa (2008: 25) „moralnie problematyczne”.

Fakt, że przekładoznawstwo ,kwestionuje nie tylko to, czy [owa przezroczystość - G.B.] jest możliwa, ale również to, czy jest pożądana” (Boase-Beier et al. 2017), stanowi pod tym względem cenny wkład w rozumienie międzykulturowego transferu pamięci. Tłumacz jako „świadek sekundarny”, świadek samego procesu dawania świadectwa (Laub 2007), to subiektywny i doświadczający podmiot wchodzący w interakcję z treścią przywoływanej przeszłości i aktywnie uczestniczący w jej zapośredniczeniu i przekazie (Deane-Cox 2013: 311; Heydel 2018). Aby osiągnąć cel, jakim jest w tym przypadku międzykulturowe i międzyjęzykowe porozumienie, zmuszony jest on często do wyjścia $\mathrm{z}$ roli zaangażowanego słuchacza i mając na uwadze czytelnika projektowanego (Brzozowski 2009), musi podejmować decyzje kształtujące tekst wyjściowy. Wiarygodność świadectwa w przekładzie nie oznacza więc konieczności usunięcia się tłumacza - wręcz przeciwnie, aktywna jego obecność jako przeżywającego autora przekładu okazuje się często jedyną drogą do uzyskania efektu autentyczności w odmiennym kontekście kulturowym (por. Davies 2008). W przypadku omawianym w niniejszym szkicu, dotyczącym bezpośredniego przekładu z języka polskiego na brazylijską portugalszczyznę, osiągnięcie tego zamierzenia wymagało od tłumaczy szeregu zabiegów wobec tekstu, których wybiórcze i zwięzłe przedstawienie będzie przedmiotem końcowej części artykułu.

jedno z zagadnień poruszonych przez nią podczas wykładu na Uniwersytecie Jagiellońskim w listopadzie 2018 roku.

9 To proponowany przez Hannę Marciniak (2013: 48) przekład wprowadzonego przez Dori Laub pojęcia secondary witness, który ma na celu uniknięcie negatywnych konotacji przymiotnika ,wtórny”, stosowanego m.in. przez Sylwię Karolak (2014: 77). 


\section{Praca w języku}

Elementem, który być może najwyraźniej ilustruje strategię przyjętą w pracy nad brazylijskim tłumaczeniem zbioru Bartnikowskiego, jest sam tytuł, w oryginale odnoszący się do ,pasiaka” jako ubioru jednoznacznie konotującego rzeczywistość obozową. W przekładach przyjęto zasadniczo dwie odrębne strategie: autorzy pierwszych opublikowanych tłumaczeń (na angielski i niemiecki) oraz tłumaczka włoska wybrali rozwiązania, które w odróżnieniu od polskiego tytułu nawiązują do obrazu drutu kolczastego (Eine Kindheit hinterm Stacheldraht, Childhood behind Barbed Wire, Infanzia dietro il filo spinato), podczas gdy autorzy przekładów na język hiszpański oraz późniejszych (na francuski, rosyjski i portugalski) postanowili zachować odwołanie obecne w oryginale (Infancia en traje de rayas, Une enfance en pyjama rayé, Dietstwo $w$ połosatych robach, Infância listrada). Zdaje się, że kluczowy dla wyjaśnienia zaobserwowanej różnicy był światowy sukces powieści Irlandczyka Johna Boyne’a z 2006 roku zatytułowanej Chtopiec w pasiastej pizamie (Boyne 2013) oraz jej ekranizacji autorstwa Marka Hermana z 2008 roku, które w kolejnych latach upowszechniły obraz obozowego „pasiaka”, a co więcej, skojarzyły go również z obecną w zbiorze Bartnikowskiego tematyką cierpienia dzieci. Przekłady niemiecki i angielski, powstałe w latach 2008 i 2009, nie korzystają z tego stosunkowo świeżego nawiązania. W 2010 roku, gdy ukazuje się tłumaczenie włoskie i hiszpańskie, Fernando Bravo García decyduje się natomiast na wybór traje de rayas (dosł. „ubranie w paski”), co wydaje się uzasadnione, jako że powieść Boyne'a, której tytuł tłumaczka Gemma Rovira Ortega oddała jako El niño con el pijama de rayas, była w Hiszpanii bestsellerem w 2007 i 2008 roku (Público 2008), podczas gdy we Włoszech nie osiągnęła podobnej popularności.

W naszym tłumaczeniu postanowiliśmy odejść od bezpośredniego odwołania do obozowego stroju i zaproponować rozwiązanie metonimiczne. Sformułowanie infância listrada (dosł. „pasiaste dzieciństwo”) zachowuje nawiązanie do „pasiastej piżamy” z tytułu powieści Boyne’a - oddanej w brazylijskiej portugalszczyźnie przez Augusto Pacheco Calila jako pijama listrado (dosł. „pasiasta piżama”, z przydawką przymiotną) (Boyne 2007) w przeciwieństwie do europejskiej pijama às riscas (,piżama w paski”, z przydawką przyimkową) w przekładzie Cecílii Farii i Olívii Santos (Boyne 2008) - lecz go nie powtarza. Pozwala to świadectwu Bartnikowskiego na 
istnienie w sposób bardziej samodzielny, bez bezpośredniego odwołania do utworu Irlandczyka. Utożsamienie tytułów - jak ma to miejsce w przypadku przekładu na język francuski, gdzie wybór padł na pyjama rayé (,,pasiasta piżama") - może rodzić bowiem wątpliwości natury etycznej, jako że zbyt mocno wpisuje autentyczne świadectwo ofiary Zagłady, która spędziła część dzieciństwa w obozie koncentracyjnym, w fikcyjne ramy wyznaczone przez narrację Boyne'a, zdaniem niektórych krytyków sytuującą się na pograniczu „bajki, opowieści [która] nie musi być dokładnie odzwierciedlać faktów” i ,profanacji” odkształcającej prawdę o Szoa (Blech 2008).

W przekładzie tytułu uniknęliśmy tłumaczenia dosłownego, które wymagałoby objaśnienia terminu ,pasiak" jako uniforme listrado, co w przypadku kultury brazylijskiej, silnie przesiąkniętej obecnością piłki nożnej, mogłoby prowadzić do niepożądanych skojarzeń z pasiastym strojem futbolowym (np. klubu piłkarskiego Santos Futebol Clube w czarno-białe pasy). Równocześnie, poprzez swoją zwięzłość i proste połączenie rzeczownika z przymiotnikiem, forma infância listrada nawiązuje do tytułów najsłynniejszych brazylijskich powieści regionalistycznych z lat 30. i 40., ukazujących często cierpienie dzieci ${ }^{10}$, wpisując treść świadectwa w ramy poznawcze odbiorców. Warto także zauważyć, że przymiotnik listrado odnosi się do rzeczywistości obozowej nie na zasadzie metafory, która językowo oddalałaby bezpośrednią obecność koszmaru Zagłady, lecz metonimii przywołującej obozowy ubiór na zasadzie przyległości ${ }^{11}$.

Wybór odpowiedniego tytułu dla brazylijskiego przekładu zbioru Bartnikowskiego sygnalizuje inne trudności praktyczne pojawiające się w procesie negocjacji między dążeniem do zachowania efektu autentyczności a czytelnością w ramach kultury docelowej. Brak w portugalszczyźnie utrwalonych, dobrze rozpoznawalanych odpowiedników terminów kluczowych dla opisu obozowej rzeczywistości, takich jak „esesman”, „blokowy”, „kapo” czy pojawiające się również w tytule słynnego opowiadania Tadeusza Borowskiego - wyrażenie „(iść) do gazu”. Większość tłumaczy na inne języki

${ }^{10}$ Między innymi Mar morto (dosł. „martwe morze”, 1936) i Seara vermelha (dosł. „czerwone pola”, co odnosi się do krwi wyzyskiwanych robotników, 1946) autorstwa Jorge Amada; Vidas secas (dosł. „suche życia”, co odnosi się do ofiar suszy, 1938) Graciliano Ramosa oraz Pedra bonita (dosł. „piękny kamień”, 1938), Riacho doce (dosł. „słodki strumień”, 1939), Fogo morto (dosł. „martwy ogień”, co oznacza niedziałający młyn cukrowy, 1943) José Linsa do Rego.

${ }_{11}$ Technika ta stanowi jedną z cech charakterystycznych poetyki Graciliano Ramosa w Vidas secas (Borowski 2016). 
oddała ostatnie z wymienionych sformułowań dość dosłownie - angielski: go to the gas; niemiecki: ins Gas gehen; włoski: andare al gas; hiszpański (objaśniający wyrażenie poprzez dodanie użycie terminu „komora gazowa”, przez co traci nieco ze swojej siły): ir a la cámara de gas; wyjątkiem jest francuski: le gaz attend (quelqu'un), dosł. ,gaz czeka (na kogoś)”. W celu oddania zwięzłości sformułowania również zdecydowaliśmy się na dosłowne ir pro gás, choć zastosowaliśmy przy tym właściwe kolokwialnej portugalszczyźnie skrócenie wyrażającego cel ruchu przyimka para i rodzajnika określonego $o$ w celu oddania potoczności wyrażenia i prostoty, która zderza się z makabrycznym wydźwiękiem.

Co się tyczy innych terminów i wyrażeń, większość tłumaczy przekłada pojawiające się z dużą częstotliwością słowo „esesman” przy użyciu odpowiedniego rzeczownika (angielski: SS-man; niemiecki: SS-Mann) lub zbliżonej struktury składniowej pozwalającej na określenie przedstawiciela organizacji lub członka oddziału (francuski: un SS; hiszpański: un SS; włoski: una $S S$ ). W tłumaczeniu na język portugalski w celu oddania perspektywy dziecka jako narratora lub fokalizatora niepojmującego początkowo organizacji życia w obozie koncentracyjnym zastosowaliśmy rozbudowaną syntagmę homem da SS (dosł. „,człowiek/mężczyzna z SS”), której od połowy zbioru towarzyszy również skrócona forma um $S S$, zbliżona do rozwiązań w innych językach romańskich, dzięki czemu dążyliśmy do oddania stopniowego, powolnego procesu przenikania do rzeczywistości obozowej.

W przekładzie na język portugalski udomowiliśmy jedynie niewielką część pojawiającej się w Dzieciństwie w pasiakach terminologii obozowej, odnoszącej się w większości do zróżnicowanych funkcji pełnionych przez więźniów i żołnierzy. Rozwiązanie to przyjęliśmy w przypadku brzmiącego naturalnie w polszczyźnie terminu „,blokowy” (oznaczającego więźnia odpowiedzialnego za porządek w bloku, rozdział żywności i ewidencję), oddanego jako chefe do bloco. W przypadku terminów, które pomimo podobnej formy wyraźniej zdradzają obce pochodzenie - takich jak słowo „sztubowy”, określające więźnia pełniącego funkcję nadzorcy w jednej z sal (niem. Stube) - zdecydowaliśmy się na zapożyczenie. Decyzja ta wpisuje się w szerszą strategię, której przyjęcie wymusiła obecność licznych określeń pochodzenia niemieckiego stanowiących integralną część obozowego socjolektu, czyli „lagerszprachy” (Wesołowska 1996). Terminy takie jak „szrajber” (pisarz obozowy; z niem. Schreiber), „torwacha” (więzień pilnujący wyjścia z baraku; z niem. Torwache) lub ,,aufzejerka” (nadzorczyni; $\mathrm{z}$ niem. Aufseherin) pomimo spolszczonej formy ukazują istotną dla realiów 
obozowych konieczność ciągłego istnienia nie tyle w odrębnych językach, ile pomiędzy językami w obliczu zbrodni, których rozmiar i okrucieństwo sytuują je już poza sferą językowego wyrazu. Wszak, jak zauważa Danuta Wesołowska, lagerszpracha to „nowa zupełnie konwencja językowa, a raczej zbiór konwencji językowych" (Wesołowska 1996: 63) służących odczłowieczeniu ofiar, wytworzonych na substracie niemieckim, choć do niego niesprowadzalnych, jako że narzucana więźniom terminologia często powodowała ich opór i wstręt (Wesołowska 1996: 43).

Ingerencję $\mathrm{w}$ ten aspekt świadectwa stanowi przyjęte przez tłumaczy na język angielski, włoski i francuski rozwiązanie polegające na zapożyczeniu powyższych nazw w niemieckiej formie (łącznie ze wspomnianymi wyżej terminami „,blokowy” oraz „sztubowy” jako Blockältester oraz Stubendienst). Wplatana swobodnie terminologia niemiecka pojawia się w dyskursie narratorów i postaci, co może rodzić błędne wyobrażenie o obozowej rzeczywistości językowej. Niejako transjęzykowy, amalgamatowy charakter spolszczonych terminów, powstałych poprzez częściowe oswojenie niemieckiego słownika w celu odnalezienia się w strukturach machiny zagłady i „ratowania się przed ostateczną klęską” (Wesołowska 1996: 43), zanika więc na rzecz dyskursu binarnego, w którym istnieje jedynie język docelowy i stojąca w wyraźnej opozycji niemiecka terminologia. O ile w przypadku tłumaczeń dzieł oryginalnie napisanych w języku niemieckim zachowanie słów opisujących schemat zarządzania obozem może pozwolić na zachowanie tego, co Arnds (2012: 170) nazywa ich „nieludzką ostrością" (inhumane edge), wyrażającą wpisane w nie okrucieństwo i odczłowieczenie, o tyle wprowadzenie ich w Dzieciństwie w pasiakach można uznać za zabieg wątpliwy etycznie. Dlatego też w przekładzie na język portugalski przyjęliśmy strategię podobną do widocznej w tłumaczeniu na język hiszpański. Pozostawiając terminy takie jak „szrajber”, „trowacha” i „aufzejerka” w oryginale, mieliśmy nadzieję zasygnalizować istnienie socjolektu, który nie jest tożsamy z niemiecką terminologią. Słownictwo to stanowi niewątpliwie element obcy dla odbiorcy brazylijskiego - który, co więcej, jego wymowy domyślić może się jedynie z podanych w przypisie odpowiedników niemieckich - jednakże warto zauważyć, że zrozumienie pojawiającej się w opowiadaniach terminologii obozowej wymaga wysiłku także ze strony czytelnika oryginału. Rozwiązanie to zdawało się właściwe moralnie, jako że pozwala uniknąć zawłaszczenia dyskursu świadka przez język należący do oprawcy. 
Refleksja formalna i etyczna towarzysząca pracy, której wybrane aspekty ukazano powyżej, przywracała nam świadomość naszej roli jako pośredników między językami i kulturami, zawieszając powracające widmo identyfikacji. Biorąc pod uwagę nasze afektywne zaangażowanie w proces przekładu świadectwa, konieczność stawienia czoła trudnościom technicznym, takim jak brzmienie tytułu czy oddanie elementów lagerszprachy, stanowiła nie tyle przeszkodę na drodze do ukończenia zadania, ile czynnik sprzyjający, istotny bufor emocjonalny, pozwalający na narzucenie dystansu wobec tekstu i kontrolę znaczeń.

\section{Pamięcio(od)twórcza rola przekładu}

Powyższe spostrzeżenia dotyczące niektórych decyzji kształtujących tekst tłumaczenia świadectwa odnoszą się do zjawiska, które można określić jako pamięcio(od)twórcza rola przekładu. Jest to rola odtwórcza, ponieważ thumaczenie świadectwa wymaga poszanowania prawd obecnych w oryginale znaczeń i możliwie (choć nigdy całkowicie) dokładnego oddania ich w kulturze docelowej. Stanowi więc, jak sądzę, cenne z perspektywy dzisiejszego przekładoznawstwa odwołanie do powszechnie kwestionowanego imperatywu wierności względem oryginału. Zarazem jest to rola twórcza, jako że wymusza na autorach przekładu wykonanie szeregu zabiegów w celu wpisania potencjalnie uniwersalnej tematyki w specyficzne pole pamięci zbiorowej (Kershaw 2014). Z punktu widzenia badań nad Zagładą zwraca więc uwagę na dynamiczny charakter międzykulturowego transferu pamięci i niemożliwość niezakłóconej transmisji przywołującej na myśl utopię idealnego powtórzenia w przekładzie.

Trzeba jednocześnie wyraźnie stwierdzić, że pełniejsze ujęcie poruszanej w niniejszym artykule tematyki i lepsze zrozumienie procesu transferu pamięci w przekładzie możliwe będzie wyłącznie poprzez zacieśnienie współpracy pomiędzy przedstawicielami translatologii i badań nad pamięcią. Jak podkreśla Susan Bassnett (2012: 23), przekładoznawstwo znajdujące się „na rozdrożu” musi „opuścić enklawę, której obszar określiliśmy i kontrolowaliśmy, lecz która miała bardzo niewielki oddźwięk poza swoimi granicami”, dzięki czemu badania nad przekładem mogą okazać się cenne i pomocne w innych dziedzinach humanistyki. Relacja ta powinna jednak, jak podkreśla Edwin Gentzler (2003), opierać się na wzajemności rozumianej jako dialog i wymiana pomiędzy dyscyplinami. 
„Świadectwa zawsze łączą się z jakimś rodzajem przekładu [i] mają potencjał, by budować wspólnoty mówiących wzdłuż różnorakich przecinających się osi przynależności - wspólnoty pamiętających, którzy być może dopiero nadejdą", stwierdza Dorota Głowacka (2014: 254). Próbę poszerzenia tej wspólnoty pamiętających podjęliśmy wraz z Edą Nagayamą w przekładzie Dzieciństwa w pasiakach na brazylijską portugalszczyznę, natomiast niniejszy szkic jest wezwaniem do budowania także wspólnoty badaczy z kręgu przekładoznawstwa i studiów nad pamięcią - postulowanej przez Saryusz-Wolską „,wspólnoty dyskursu”, która być może dopiero nadejdzie.

\section{Bibliografia}

Adamowski J., Wójcicka M. (red.). 2012. Pamięć jako kategoria rzeczywistości kulturowej, Lublin: Wydawnictwo UMCS.

Agorni M. (red.). 2014. Memoria, lingua, traduzione, Milano: Franco Angeli.

Anderson M.H. 2007. The Child Victim as Witness to the Holocaust. An American Story?, „Jewish Social Studies” 14(1), s. 1-22.

Arbex D. 2013. Holocausto brasileiro, São Paulo: Geração Editorial.

Arnds P. 2012. Translating Survival, Translation as Survival in Primo Levi's Se questo è un uomo, „Translation and Literature” 21, s. 162-174.

(red.). 2015. Translating Holocaust Literature, Göttingen: V\&R Unipress.

Bartnikowski B. 2016a. Dzieciństwo w pasiakach, Oświęcim: Państwowe Muzeum Auschwitz-Birkenau.

2016b. Eine Kindheit hinterm Stacheldraht, przeł. W. Hölscher-Valtchuk, Oświęcim: Staatliches Museum Auschwitz-Birkenau.

2016c. Childhood behind Barbed Wire, przeł. T. Pobóg-Malinowski, Oświęcim: Auschwitz-Birkenau State Museum.

_2016d. Infanzia dietro il filo spinato, przeł. A.L. Guglielmi Miszerak, Oświęcim: Museo Statale di Auschwitz-Birkenau.

2016e. Infancia en traje de rayas, przeł. F. Bravo García, Oświęcim: Museo Estatal de Auschwitz-Birkenau.

- 2016f. Une enfance en pyjama rayé, przeł. A. Dayet, Oświęcim: Musée d’État d'Auschwitz-Birkenau.

2018a. Dietstwo w połosatych robach, przeł. N. Iwaniec, Oświęcim: Gosudarstvennyy Muzey Osventsim-Birkenau.

2018b. Infância listrada, trans. G. Borowski, E. Nagayama, Oświęcim: Museu Estatal de Auschwitz-Birkenau.

Bassnett S. 2012. Translation Studies at a Cross-roads, „Target” 41(1), s. 15-25.

Bilczewski T. 2013. Trauma, translacja, transmisja w perspektywie postpamięci. Od literatury do epigenetyki, w: T. Szostek, R. Sendyka, R. Nycz (red.), Od pamięci biodziedzicznej do postpamięci, Warszawa: IBL PAN, s. 40-62. 
Bines R.K. 2011. Samba and Shoah. Ethnic, Religious and Social Diversity in Brazil, „European Review of History — Revue Européenne d'Histoire” 18(1), s. 101-109.

Blech B. 2008. The Boy in the Striped Pajamas. This Well-meaning Book Ends up Distorting the Holocaust, „Aish.com”, 23 października, http://www.aish.com/j/ as/48965671.html (dostęp: 21.11.2018).

Boase-Beier J. 2015. Translating the Poetry of the Holocaust. Translation, Style and the Reader, London: Bloomsbury.

Boase-Beier J., Davies P., Hammel A., Winters M. (red.). 2017. Translating Holocaust Lives, London: Bloomsbury.

Borowski G. 2016. Oszukać głód: o trudnościach w przekładzie estetyki niedostatku na przykładzie powieści Zwiędłe życie Graciliano Ramosa, w: E. Kujawska-Lis, I.A. Ndiaye (red.), Komunikacja międzykulturowa $w$ świetle współczesnej translatologii. Teoretyczne i praktyczne aspekty przekładu literackiego, Olsztyn: Katedra Filologii Angielskiej UWM, s. 27-40.

Boyne J. 2007. O menino do pijama listrado, przeł. A. Pacheco Calil, São Paulo: Seguinte. 2008. O rapaz do pijama ás riscas, przeł. C. Faria, O. Santos, Vila Nova de Gaia: Asa.

2013. Chtopiec w pasiastej piżamie, przeł. P. Łopatka, Dopiewo: Replika.

Brownile S. 2016. Mapping Memory in Translation, Houndmills, Basingstoke: Palgrave Macmillan.

Brzozowski J. 2009. Czytelnik projektowany w przekładzie. Problem paratekstu, w: Czytane w przekładzie, Bielsko-Biała: Wydawnictwo ATH, s. 51-60.

Budrewicz Z., Sendyka R., Nycz R. (red.). 2014. Pamięć i afekty, Warszawa: IBL PAN. Davies P. 2008. The Obligatory Horrors. Translating Tadeusz Borowski's Holocaust Narratives into German and English, „Holocaust Studies” 14(2), s. 23-40.

- (red.). 2014. „Translation and Literature” 23(2), numer tematyczny „Holocaust Testimony and Translation".

2018. Witness between Languages. The Translation of Holocaust Testimonies in Context, Rochester, NY: Camden House.

Deane-Cox S. 2013. The Translator as Secondary Witness. Mediating Memory in Antelme's L'espèce humaine, „Translation Studies” 6(3), s. 309-323.

DiAntonio R. 1991. Redemption and Rebirth on a Safe Shore. The Holocaust in Contemporary Brazilian Fiction, „Hispania” 74(4), s. 876-880.

Dizdar D. 2009. Translational Transitions. ,, Translation Proper” and Translation Studies in the Humanities, ,Translation Studies” 2(1), s. 89-102.

Drummond R. 1984. Hitler manda lembranças, Rio de Janeiro: Nova Fronteira.

Gentzler E. 2003. Interdisciplinary Connections, „Perspectives” 11(1), s. 11-24.

Głowacka D. 2014. Wieża Babel. Świadectwa Holokaustu a etyka przekładu, przeł. Z. Ziemann, „Przekładaniec” 29, s. 229-255.

Hałas E. (red.), 2012. Kultura jako pamięć. Posttradycyjne znaczenie przeszłości, Kraków: Nomos.

Heydel M. 2009. Zwrot kulturowy w badaniach nad przekładem, „Teksty Drugie” 6, s. 21-33. 
Heydel M. 2018. ,Wszystkich przestuchano, tylko nas nie”. Thumacz ustny jako świadek, „Teksty Drugie” 3, s. 267-280.

Hubscher-Davidson S. 2017. Translation and Emotion. A Psychological Perspective, New York-Oxon: Routledge.

Jakobson R. 2009. O językoznawczych aspektach przekładu, przeł. L. Pszczołowska, w: P. Bukowski, M. Heydel (red.), Wspótczesne teorie przektadu. Antologia, Kraków: Znak, s. 43-49.

Karolak S. 2014. Od pamięci do postpamięci. Literatura polska wobec Zagłady, w: A. Popławska, B. Świtalska, M. Wasilewski (red.), Pamięć - Pogranicze - Oral History, Warszawa: Wydawnictwo UKSW, s. 70-78.

Kansteiner W. 2017. Transnational Holocaust Memory, Digital Culture and the End of Reception Studies, w: T.S. Andersen, B. Törnquist-Plewa (red.), The Twentieth Century in European Memory. Transcultural Mediation and Reception, LeidenBoston: Brill, s. 305-343.

Kershaw A. 2014. Complexity and Unpredictability in Cultural Flows. Two French Holocaust Novels in English Translation, „Translation Studies” 7(1), s. 34-39.

_ 2018. Memory Studies, w: L. D'hulst, Y. Gambier (red.), The History of Modern Translation Knowledge. Sources, Concepts, Effects, Amsterdam-Philadelphia: John Benjamins, s. 273-276.

Kończal K. (red.). 2014. (Kont)Teksty pamięci, Warszawa: Narodowe Centrum Kultury, s. $9-13$.

Laub D. 2007. Zdarzenie bez świadków. Prawda, świadectwo oraz ocalenie, przeł.

T. Łysak, ,Teksty Drugie” 5, s. 118-130.

Levin I. 1992. Chłopcy z Brazylii, przeł. M. Miganowska, Warszawa: W. Pogonowski. Malena A. (red.). 2016. „TransCulturAl” 8(1), numer tematyczny „Translation and Memory"

Marciniak H. 2013. Wizualna przestrzeń postpamięci. Poetyka sekundarnego świadectwa $w$ nożyku profesora Tadeusza Różewicza, „Wielogłos” 1(15), s. 47-61.

Público 2008 = El niño con el pijama de rayas sigue batiendo récords, „Público”, 23 października, https://www.publico.es/culturas/nino-pijama-rayas-sigue-batiendo. html (dostęp: 21.11.2018).

Saryusz-Wolska M. 2010. Zapomnieć się w pamięci. Pytania o badanie pamięci kulturowej, „Kultura Współczesna” 1(63), s. 76-86.

Saryusz-Wolska M., Traba R. (red.). 2014. Modi memorandi. Leksykon kultury pamięci, Warszawa: Scholar.

Seligmann-Silva M. 2007. Literatura da Shoah no Brasil, „Arquivo Maaravi” 1(1).

Spiessens A. 2018. Featured Member: Anneleen Spiessens, „Cultural Memory Studies Initiative", 31 sierpnia, http://www.cmsi.ugent.be/featured-member-anneleenspiessens/ (dostęp: 21.11.2018).

Viradouro 2008 = Unidos do Viradouro, carnaval de 2008, „Galeria do Samba”, http:// www.galeriadosamba.com.br/escolas-de-samba/unidos-do-viradouro/2008/ (dostęp: 21.11.2018).

Wesołowska D. 1996. Słowa z piekiet rodem. Lagerszpracha, Kraków: Impuls.

Wichrowska E. et al. (red.). 2015. Historie afektywne i polityki pamięci, Warszawa: IBL PAN. 